\title{
Determining the University's Goals: the Setting of the Problem
}

\author{
DUNCAN D. CAMPBELL ${ }^{*}$
}

\begin{abstract}
The Canadian university has moved from a decade of rapid expansion, accompanied by general public approval, to the so-called "steady state," of the 1970's, characterized by sharp public questioning of its directions and of its relevance. Criticism from both public and academics alike centres on the lack of consensus within the institution as to its purposes. Certain major factors have the potential to influence a university's choice of goals. Some of these flow out of the network of relationships of the university with its external environment while others stem from the social world of the institution itself. The paper concludes that, given expressions of public concern and what appear to be basic shifts in the fabric of Canadian society - and thus of its requirements of higher education - the re-consideration of institutional goals has become vital.
\end{abstract}

Clarifying utopian abstractions, and distinguishing between objectives for institutional development and for student development, not only sets a framework for evaluation, but also lays a cornerstone for educational improvement and financial survival. Institutional effectiveness improves when objectives are held in awareness and when they are articulated in concrete terms. Efforts to clarify objectives and to increase self-consciousness about them can release strong forces for institutional improvement.

\section{Arthur W. Chickering}

During the 1960's the Canadian university might well have afforded to be complacent about its role, its performance, and its future. The need to solve pressing problems of providing space for a rapidly increasing student body, of recruiting staff, of developing libraries and laboratories, tended to push the fundamental question of direction to the periphery. Universities produced a steady stream of professionals. A larger body of consultants and researchers was placed at public service. That decade, in short, was one of rapid expansion accompanied by general public approval.

Today, public attitudes reflect not acceptance but anxiety. Students, parents, legislators, and major public bodies are critical and questioning. Assurance in the public mind of the efficiency - and of the effectiveness - of the university's performance has been shaken. How relevant, the public speculates, is today's university to contemporary society?

${ }^{*}$ Professor of Higher Education, University of Alberta 
The climate of opinion now enveloping the university is linked to changes in the institution itself. There is abroad the belief that higher education should be open to everyone, that a general broadening of higher education is in the public interest. The student body, itself, has become more sophisticated and urbane, more aware of the environment in which it lives and demonstrably less bound by traditional values. University communities, too, are today pluralistic. An earlier, standard university orthodoxy has been succeeded by diversity and heterogeneity within the collective institution. The very term "community," frequently applied to the university, seems no longer applicable. Indeed, the university seems to have been taken over by professionalism and its reward structure geared to professional rather than institutional values. Academic departments, now much stronger, reinforce the grasp of professionalism on the institution. Among departments and among individual faculty members, students, and administration, there is sharp cleavage as to means and ends in higher education.

Nor does the university lack in public criticism:

Many of the sources of public disaffection are obvious: the soggy economy, the student rebellion, professors who earn more by teaching less, etc. But far more fundamentally, it appears that the public is demonstrating its concern about the purposes that higher education has been asked to serve. . . in higher education, as in so many other areas of American life, the public is demanding a reassessment of our priorities, not the dismantling of the system. (Cass, 1971:61)

But in the vanguard of the critics are the academics themselves, of whom one (Martin, 1967:230) observes that

differences of opinion arise, then, not over the basic nature of the university but over what forms its service shall take, and with what priorities. It is the lack of agreement on these issues that divides the university and makes it indecisive.

Even that assumption of agreement on the university's basic nature is denied by a contemporary study (Study Commission on University Governance, 1968: 7-8) which holds that

the melancholy truth is there is no widely shared understanding about the meaning and purpose of the institution. Lacking the unifying force which flows spontaneously from common understanding, the system is held together by a bureaucratic organization whose weakness is exposed whenever it is directly challenged.

These sentiments have their Canadian echoes:

If there is a single cause which is to be blamed for the shortcomings of present government-university relations more than any other, it is probably the lack of clarity about the aims of higher education [and] by lack of clarity of purpose we do not mean the great normative justifications for education generally, or for universities specifically. (Commission on the Relations Between Universities and Governments, 1970:80).

And the former president of Toronto's frequently embattled York University (Ross, 1970:12) observes out of hard experience that

The most critical problem in the university today is the lack of consensus about purposes and functions. Among members of faculty there are widely divergent views about the university's role in society, about what should be taught and how it should be taught, about examinations and grades, about the kind of research that should be 
sponsored, about who should be in university, and about many other questions. These differences are so great as to appear almost irreconcilable. It may be that we are witnessing the breakdown of the university as we have known it, and that entirely new forms of higher education will appear.

What seems often apparent is that, in consequence of a lack of common understanding of institutional direction, educational change becomes a function of pressure rather than of rational planning. There is thus pressing reason for the university to re-examine its directions. But, as has been frequently and sardonically observed, methods of social research - especially that based on empirical data - have been applied by university professors to every important institution but their own. Certainly, the path of that research is not easy. Among the obvious obstacles is the factor of sheer size; the organization of the university as a conglomerate of bureaus, departments, institutes, and faculties; the orientation of faculty towards discipline rather than institution; and the difficulty of evaluating performance in the multi-purpose institution.

There are, moreover, at least three sets of biases responsible for opposition to selfexamination of a fundamental kind within the university. There is the belief that educational outputs cannot be measured and that any attempt to do so is ludicrous, if not actually subversive of the purpose of the institution. There is the notion of inherent conflict between administrative efficiency, on the one hand, and academic effectiveness on the other. And there is the suspicion that efforts to improve management efficiency are really designed to increase the power of the administrator at the expense of the faculty member.

What potential values, what outcomes, might accrue to such a study? Clark Kerr (1963:38) passes off the entire matter of institutional purpose in a single sentence: "The ends are already given - the improvement of service wherever truth and knowledge of high order may serve the needs of man." But this somewhat theatrical statement hardly serves as a signpost to the university. Generalities or abstractions are no substitute for an operationally useful statement of intent. Clearly, the clarification of institutional goals is a necessary preface to the evaluation of progress. The understanding of the goals of the immediate past are relevant to the postulation of the goals for the immediate future. Thus, Uhl (1971) proposes that the identification of present goals is a necessary step towards developing a convergence of opinion on future directions. Further, the university's goals must be defined, if only to differentiate it from the many other like institutions and activities with which it is in association, among them technical institutes, professional schools, and community colleges.

The objection is raised that the achievement of greater coherence and clarity by individual universities would tend to make them more alike as institutions. On the contrary, it is rather more likely that the clarification of focus by each university would lead to a greater stress on its individuality and style as an institution. Beyond that, it would facilitate better response to the queries and demands of a budgeteer and would increase the likelihood that institutional supporters and critics would direct their aid or shape their criticisms to its chosen purposes and not to theirs.

If, as the organization theorists have it, the seven steps in the planning process move through an articulation of philosophy, a statement of goals, the development of program and of organization, the recruitment of staff, the construction of facilities, and financing - the clarification of goals is a vital initial step. 
Finally, there is value in the study of goals as a contribution of considerable significance to the development of a theory of organization in higher education. While individuals may well have considerable insight into organizations as social instruments,

insight and private experiences may generate private understandings without producing a public body of knowledge adequate for the preparation of a next generation of administrators, for designing new styles of organizations for new purposes, for controlling organizations, or for appreciation of distinctive aspects of modern societies. (Thompson, 1967:3)

Major factors, both internal and external, bear on a university's choice of goals.

Some of them originate from the organization's external environment, which is ambiguous indeed. Not only are problems received from it not clearly defined, but also those that appear clearly formulated may, in fact, be misleading. It is complicated and multi-faceted; so much so that out of necessity relatively simplistic images of the world must suffice to serve the organization's administrative needs. Nor is each part of the organization at all likely to view the environment from an identical perspective. That part of the environment which reinforces one group's perceptions within the organization may threaten those of another (Dill, 1964).

Moreover, the environment itself comprises not one but a number of different publics. There is, for example, the larger society which permits the organization to operate; there is that part of the total society which provides a pool of potential members; there are those other bodies with which the organization competes, cooperates, or has transactions with; and there is "the public-in-contact" with whom or on whom the organization's members work. Other sets of publics, somewhat different, which interrelate with the organization and have impact on it might be identified, as in this example (Gross, 1964:411):

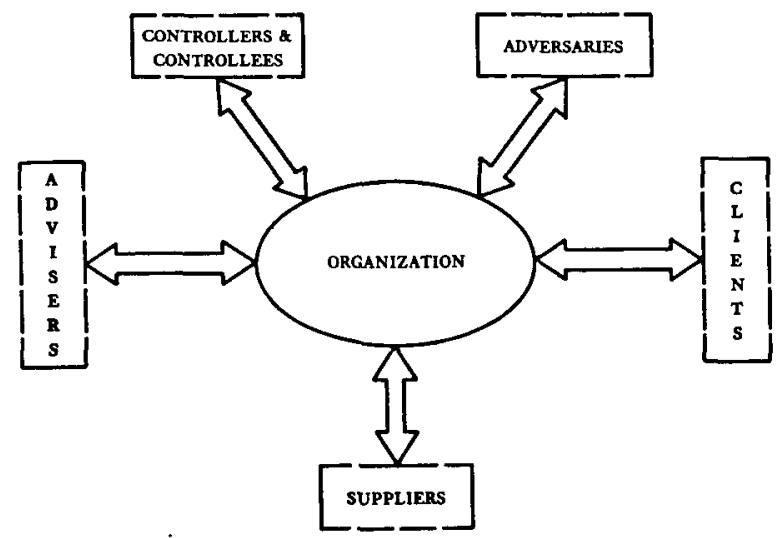

The demands of these publics are diverse - or even conflicting. Business expects the university to supply consultants; government bureaus expect to draw on its expertise in research; cities and towns expect the university to offer extension courses and maintain a role as an intellectual and cultural centre. And so, as Werdell (1968:20-21) pessimistically observes, 
administration of a multiversity is, almost by necessity, a holding action. In the face of conflicting demands and purposes, balance among the competing forces is reluctantly substituted for the more difficult task of molding an institution that best fosters diversity among its students.

However these publics may be delineated, the university is interdependent with the society of which it is a subsystem. The university depends on outside sources for political and economic support, even when its product is not of immediate "use." It depends on society for its legitimation. At the same time, the university makes contributions upon which society has come to depend. Indeed, "The academic and non-academic worlds are not only interdependent, they are interpenetrating" (Parsons, 1968:174).

But academics do not unreservedly accept a sense of partnership between the university and the society that nurtures it. A separateness from society, a freedom for the university to set its own goals independent of society, is the essential ingredient of yet another view. Here, the university is seen not as a production line in the service of existing society but rather as an institution charged with the essential function of criticism of society and the diagnosis of its ills. Consequently, the university must remain if not irresponsible in its relationship to the community, at least willing to incur the risk of antagonizing interests and groups within it. Paradoxically, it may be the duty of the university, as occasion warrants, to bite the hand that feeds it (MacPherson, 1968:99).

The university thus influences society and is influenced by it. Within the university institution, certain interdependencies are of particular significance. There is the influence of the alumni, described as a kind of "family" relationship felt in and out of the university's councils. Contractual research has its impact on curricula, faculty membership, facilities, and budgets. Accrediting bodies and professional associations, too, have their effect on admission requirements and academic standards. And the university may be influenced both directly and indirectly by private donors or foundations. In passing, one notes the tendency, not typical in business, of outside groups to apply pressure to the institution (without accepting a commensurate obligation to support or contribute to it) and the intimacy with which their representatives operate in the decision-making councils of the institution (Corson, 1960). Wriston (1937:20), summarizes the essence of the matter:

If the college were wholly alien to its environment, it could not perform its function. ... On the other hand, if it yields completely to its environment, it equally fails in its objectives. It must maintain a realistic contact without compromising its essential function.

But it is the factor of relationships with government which is paramount. That relationship has changed, never to be the same.

It is useless to imagine that universities can be forever free from national pressures, political and social. It is useless, indeed dangerous, to imagine that university autonomy is something capable of definition in eternally comprehensive terms. It is useless to imagine that the elements of reciprocal influence and authority between university systems and others can ever be regarded as fixed. Nor can jurisdictions be regarded as fixed. Academic security can never come in this manner. Neither governments nor universities can hope to exempt themselves from those changes which it is not the least of their functions, within their appropriate fields, to encourage. But the characteristic mark of 
the liberal government in its relations with universities is the attitude of partnership; and the characteristic of the wise university in sealing that relationship is that, like any partner, it must share the losses as well as the gains. There is some evidence that neither party has fully realized its role, but, in my submission the greater responsibility at this point of our history lies with the universities. (Cooper, 1966:19-20)

In Canada, relationships of universities to government seem closer to that of reluctant competitors, sparring in their respective corners. A forbidding alternative to mutual adjustment here, as elsewhere, is a major infiltration of the state into higher education. Abundant illustration exists in other jurisdictions of political domination, not only of higher education functions but of administrative control (Moos and Rourke, 1959). From the viewpoint of government, arguments for control are substantial. There is the expectation that control devices might offer savings in rapidly escalating budgets. Certain practices in higher education, government argues, cry out for remedy as, for example, the lack of coordination among institutions and the inefficient distribution of educational functions among them. Legislators are disturbed by the idea of inter-institutional competition, not only in programs of instruction but also for students. To which might be added their uneasy speculation that university authorities are not making full disclosure of the truly pertinent facts. Thus far in Canada, though province and university are now intimately bound by the umbilical cord of finance, there is little evidence of administrative control of the university.

Government aside, there are other factors in the university's external environment which affect its choice of goals. Jacques Barzun (1968:243-246), a sharp and frequent critic of the American university, argues that "if the university is to save itself by making the changes that it is already eager and able to make, it must act not singly but in groups." A university, for example, can scarcely afford substantial modification to a Ph.D. degree lest it be seen as a dilution of that degree, a depreciation of its prestige value, and thus risk the ship's rat effect of students and professors fleeing the sinking hull. The argument, of course, is not against change; rather, Barzun proposes that, while the individual institution must in spirit remain a single entity, "it should from time to time join with other universities to introduce ripened innovations." In more subtle ways, too, the influence of other institutions may be felt. Doubtless, many North American institutions have been influenced by images held by their staff of such academic titans as the University of Chicago, Harvard, the Massachusetts Institute of Technology, or Berkeley. Nor is the influence of institutions over one another to be measured solely in terms of emulation. A potential determinant of goals is institutional rivalry - of which examples abound - a motivation which can mobilize and bind the group to group goals, whether or not those goals best meet public need.

Public and quasi-public bodies have their impact on the goals of universities. Indeed, a major characteristic of our time is the extent to which institutional planning is now being undertaken external to universities. In Canada, the recommendations of the Massey Commission (Royal Commission on National Development in the Arts, Letters, and Science, 1950) led to the establishment of the Canada Council which, in turn, has profoundly influenced the arts, humanities, and social sciences. The Duff-Berdahl Commission (1966), both in the timing and content of its report, affected the re-shaping of university government in Canada. The Report of the Senate Special Committee on Science Policy (1971) will, in the long term, significantly shape the research policy of Canadian universi- 
ties in the sciences. Similarly, the reports of Royal Commissions appointed in Ontario (Commission on Post-Secondary Education in Ontario, 1972), Alberta (Commission on Educational Planning, 1972), and Manitoba (Task Force on Post-Secondary Education in Manitoba, circa 1973) will modify the goals of higher education.

The internal social world of the university, too, affects its choice of goals. The formal structure of the organization does not wholly describe it since it is invariably supplemented by an informal structure which reflects the personalities of individuals with their special problems and interests.

Of central importance among these internal factors is the element of leadership. In one view, the characteristics of the responsible leader are to be summarized under two headings: the avoidance of opportunism and the avoidance of utopianism. The former is the pursuit of immediate short-run advantage without reference to principle or ultimate consequence. Utopianism, on the other hand, "hopes to avoid hard choices by a flight to abstractions." The heart of this argument concerns the responsibility of leadership in setting goals and the vulnerability of institutions in which goals are unclear.

Leadership is irresponsible when it fails to set goals and therefore lets the institution drift. The absence of controlling aims forces decisions to be made in response to immediate pressures. Of course, many large enterprises do drift, yet they survive. The penalties are not always swift, and very often bare survival is possible even though the fullest potentialities of the enterprise are not realized and significant changes in identity do occur. (Selznick, 1969:186)

The principal danger of short-run practical adaptations - of opportunism - lies in their uncontrolled and usually negative effects on organizational character. The carefully cultivated charisma of special competence may become vague and abstract. What are claimed as goals may, in fact, be merely a rationalization of activities arising out of opportunistic decision-making.

Another danger is equally important: an excessive response to outside pressures. While the leadership must take account of the environment and adapt both to its limitations and opportunities, institutional surrender must not be made in the name of organizational survival. The danger is real that outside elements may invade the organization, so dominating parts of it that it is no longer truly independent. Utopianism - the over-generalization of purpose - may leave the institution vulnerable to both external and internal pressures. Generality in purpose is congenial to the opportunism of external - and internal - groups. Institutional continuity and identity are to be protected by that definition of mission which sets out distinctive character and abilities.

Organizational structure, like leadership, is an important internal element determining goals. Neal Gross (1963) argues in his study of organizational lag in universities that, historically, the basic approach of the North American university has not been that of a functional division of labor among the members of its faculty but rather the periodic redefinition of academic roles so as to encompass the diverse tasks it has come, over time, to assume. While other kinds of organizations have met proliferating functions with increased specialization, the university has chosen to heap function after function on its personnel.

But, though universities have assumed a variety of new organizational objectives, the primary criterion of the reward system used to evaluate individual performance remains 
that of productivity in research, tied to which is consulting, which flatters both ego and pocketbook. Here lies a basic anomaly: though the reward system gives highest priority among the several functions of the university to the advancement of knowledge, the basic organization of most universities is that of an agency whose primary function is the transmission of knowledge.

A basic structural change which has its consequences for the choice of institutional goals is the trend towards the granting of increased autonomy to organization sub-units within the institution. The history of higher education over a half-century has been one of a diminution of power by boards of governors and presidents in the control of academic affairs. What now seems apparent is that the department has become the keystone of the university's structural framework, the home base of varieties of professionalism which may - or may not - be in tune with the values of the institution. Many have noted this phenomenon, characterizing the modern university as a miscellaneous collection of faculties, research institutes, hospitals, laboratories, and departments - held together by a common concern over parking. "If the Edsel were a department," Paul Grambsch (1970) quips, "it would still be in production." This fragmentation has its bleak consequences in

the development of some faculties at the expense of others, the neglect of liberal education in order to meet the needs of the professional and technical schools, marked discrepancies in the standards among faculties on the same campus, the donation of funds to marginal activities because the needs of the whole institution are not effectively presented, the submerging of one or more basic disciplines in a single professional school, and the lack of interdisciplinary teaching and research programs. (Corson, 1960: 21)

There are other elements of university structure affecting goals: the degree of power of the faculty as a body over educational policies; the pressure on the university president to give primacy to such functions as finance and public relations rather than to the academic problems of the university; and the steadily diminishing power of the board of governors over the internal operation of university affairs. Size is a further factor which has a bearing on institutional functioning and goal choice, though this dimension does not appear to have been the object of much investigation. One observes, however, that as an institution matures and expands, the structural elements which comprise it become more varied and its sense of direction more diffuse. That diversity may well militate against the achievement of a constructive consensus on goals.

Among the factors internal to the organization which tend to shape organizational goals (and which makes the specification of those goals a matter of such great complexity) is the behavior of its members. Empirical evidence of this relationship is scarce. Yet all academics will have observed "that no small part of the problem of governance in higher education may be traced to the predisposition of members of the academic community to interpret the same events quite differently." (Pfnister, 1970:9). The problem created by these different perceptions may well become acute, particularly when faculty and administration are the two parties involved. Nor is it merely a matter of "poor communication" - the stock phrase. The real difficulty is that though individuals hear one another quite well, they have quite different interpretations of what they see and hear. Faculty 
and administration members living on the same premises, Pfnister observes, may not operate on the same premises. The same observation might be applied to the various faculties and schools which comprise the institution.

It is somewhat startling to realize that there may indeed be a wide gulf between men whose training, concerns, and values, have lain in the general areas of scientific pursuits, and men of nontechnical background.... [accompanied by the] danger that the divergence of experience set and harden a real and fundamental dichotomy of attitudes and values between the two worlds, and encourage an unbridgeable hostility between them. (Haskins, 1960:147)

And, to add to the complexity, different units of the university may well support the same goals - for different reasons.

Academics who have shared in the administration of the institution confirm that colleagues respond to problems in a fairly predictable way. Several social scientists have attempted the classification of participants within the organization in terms of the roles they play in its functioning. Perhaps best known is Gouldner's (1957, 1958:448) classification of "Cosmopolitans" and "Locals" in reference to the orientation or attachment of academics to their institutional base. Within the Cosmopolitans are the Outsiders and the Empire Builders. Among the Locals - those close to the institutional base - are the supportive Dedicated, the True Bureaucrats, loyal to the place itself; the Home Guard, who have the least occupational specialization and commitment, who tend to be neither full-time researchers nor teachers but rather administrators, and who do not occupy the highest administrative positions but are on the second rung; and, finally, there are the Elders, long standing members of the organization with a deep and permanent commitment to the organization.

Other members in the typical organization are characterized as "unique troublemakers" (Moore, 1962); or in terms of how accepting members are of the organization's intentions in the disposal of their energies (Caplow, 1964); or according to their upward mobility (or indifference to it) within the organization (Presthus, 1962); or as groups of them may be apathetic, erratic, strategic, or conservative (Sayles, 1958).

And finally, an element which seems certain in the future in Canadian universities to affect the goal-determining processes of the institution is the affiliation of staff, academic and non-academic alike, with organized labour. One can only speculate on the effect, not just on institutional goals but on structure, organization, and finance, to say nothing of the more subtle potential influences on the spirit of the university - that elusive intangible which distinguishes its unique place in society. Collective bargaining, whether organized under a provincial labour code or under a revised university act, would seem amost inevitably to affect institutional balances and goals. It is not difficult to imagine that the sharp differentiation of roles implicit in an employer-employee contract might lead to the calcification of postures and to the exacerbation of conflict. One surmises that democracy, as a significant value, might find itself opposed to the achievement and maintenance of academic excellence. The argument on the other side - perhaps less convincing - is that staff discontent having been resolved through the creation of a bargaining unit, employer and employee would join in unalloyed amity to plan institutional directions.

There are today four general perceptions of the university. There is the university 
viewed as elitist in character or, alternatively, as expansionist in nature ever broadening the range of its service to society. There is the notion of the university as an institution primarily inclined towards the preservation of knowledge and its transmission to students; and the university devoted to the creation of new knowledge. Which of these or what balance of these will best serve contemporary society?

Sir Walter Moberly (1949) writing in The Crisis in the University poses questions which continue relevant. "What are universities for?" "What effect should they have on their alumni?" "What are their responsibilities to the outside world?" Answers from on and off the campus are discordant and unclear. Yet institutional self-confidence and strength spring only out of agreement on a sense of direction.

All of society's institutions in the last half-century have been challenged and threatened to one degree or another by accelerating change. A difficult and profound question is how seriously to take this change. It is an entirely defensible view - one which infuses the argument above - that there is indeed a widening chasm between the safe, pat, past, and an eerie future. In consequence of this change, the university is obliged to take stock of itself.

The task of re-defining goals is to be undertaken not merely as a sop to a querulous public nor as a maneuver to win political support from legislators. What is at issue is the continued vitality of each institution. That vitality is not to be found, as Robert $\mathrm{K}$. Merton observes, in the quest for continually improved means to carelessly examined ends. 


\section{References}

Barzun, Jacques (1968). The American University. New York: Harper and Row. 243-246.

Caplow, T. (1964). Principles of Organization. New York: Harcourt, Brace \& World.

Cass, J. (1971). "Has the Bubble Really Burst?," Saturday Review. Vol. LIV, No. 16.

Commission on Educational Planning (1972). A Choice of Futures. Walter H. Worth Commissioner. Edmonton, Alberta: L. S. Wall, Queen's Printer.

Commission on Post-Secondary Education in Ontario (1972). The Learning Society.

Toronto, Ontario: Ministry of Government Services.

Commission on the Relations Between Universities and Governments (1970). The University, Society and Government. René Hurtubise and Donald C. Rowat, Commissioners. Ottawa, Ontario: University of Ottawa Press.

Cooper, W. M. (1966). "Change in Britain," in W. M. Cooper, et al, Governments and the University. Toronto, Ontario: The Macmillan Company of Canada. 19-20.

Corson, J. J. (1960). Governance of Colleges and Universities. New York: McGraw-Hill Book Company. 35-38, 143-165.

Dill, William R. (1964). "Decision Making," in Daniel E. Griffiths, ed., Behavioral Science and Educational Administration. Chicago: The University of Chicago Press.

Duff, Sir James, and Berdahl, Robert O., Commissioners (1966). University Government in Canada. Toronto, Ontario: University of Toronto Press for the CAUT and the AUCC. Gouldner, A. W. (1957, 1958). "Cosmopolitans and Locals: Toward an Analysis of Latent Social Roles," Administrative Science Quarterly. Vol. 2, No. 3 (1957) and No. 4 (1958). 448.

Grambsch, P. V. (1970). "Conflicts and Priorities," in G. Kerry Smith, ed., The Troubled Campus. San Francisco: Jossey-Bass.

Gross, B. M. (1964). Organizations and Their Managing, I. New York: The Free Press. Gross, N. (1963). "Organizational Lag in American Universities," Harvard Educational Review. Vol. 33, No. 1.

Haskins, Caryl P. (1960). "Society and Scientific Research," Bulletin of the Atomic Scientists. Vol. XVI, No. 5.

Kerr, C. (1963). The Uses of the University. New York: Harper Torch-books, Harper and Rowe Publishers.

Macpherson, C. B. (1968). AUCC Proceedings of Annual Meeting. See also Macpherson, C. B. (1970). "The University as Multiple Fool," CAUT Bulletin. Vol. 19, No. 1, 3-7.

Martin, W. B. (1967). "The University as Community," Educational Record. Vol. 48, No. 4.

Moberly, Sir Walter, (1949) The Crisis in the University. London: S.C.M. Press.

Moore, W. E. (1962). The Conduct of the Corporation. New York: Random House.

Moos, Malcolm, and Rourke, Francis E. (1959). The Campus and the State. Baltimore:

The John Hopkins Press.

Parsons, Talcott (1968). "The Academic System: A Sociologist's View," The Public Interest. No. 13.

Pfnister, A. O. (1970). "The Role of Faculty in University Governance," Journal of Higher Education. Vol. XLI, No. 6.

Presthus, Robert (1962). The Organizational Society. New York: Vintage Books. 
Ross, Murray G. (1970). "A Businesslike University is an Impossibility," Toronto Globe Magazine. November 14, 1970.

Royal Commission on National Development in the Arts, Letters, and Science, 1950. Ottawa: Queen's Printer, 1951.

Sayles, Leonard R. (1958). Behavior of Industrial Work Groups. New York: Wiley. Selznick, P. (1969). "Leadership in Administration," in Amitai Etzioni, ed., Readings on Modern Organization. Englewood Cliffs, New Jersey: Prentice Hall.

Senate Special Committee on Science Policy (1971). A Science Policy for Canada, Vol. I: A Critical Review - Past and Present, 1970, Vol. II: Targets and Strategies for the Seventies. Ottawa, Ontario: Queen's Printer.

Study Commission on University Governance (1968). The Culture of the University: Governance and Education. Berkeley: University of California.

Task Force on Post-Secondary Education in Manitoba (circa 1973). Post-Secondary Education in Manitoba. Winnipeg, Manitoba: Queen's Printer.

Thompson, J. D. (1967). Organizations in Action. New York: McGraw-Hill. 3.

Uhl, Norman P. (1971). Encouraging Convergence of Opinion, Through the Use of the Delphi Technique in the Process of Identifying an Institution's Goals. Princeton, New Jersey: Educational Testing Service. 1.

Werdell, P. R. (1968). "Teaching and Learning: Whose Goals Are Important Around Here?," in Charles G. Dobbins and Calvin B. T. Lee, eds., Whose Goals for American Higher Education? Washington, D. C.: American Council on Education.

Wriston, H. M. (1937). The Nature of the Liberal Arts College. Appleton, Wisconsin: Lawrence College Press. 20. 